\title{
Role of Education on Spiritual Intelligence between Science and Arts Undergraduate Students
}

\author{
Nancy Agrawal ${ }^{1}$, Prof. Mahmood S. Khan ${ }^{2}$
}

\section{ABSTRACT}

Intelligence plus character is the goal of true education (Martin Luther King, Jr.). Education must also guide one for fast, firm and successful thinking. Educational achievement is associated with many life outcomes, including income, occupation and many health and way of life variables. A great majority of the so-called educated people do not think logically and logically. Even the press, the classroom, the platform, and the stage in many instances do not give us objective and unbiased truths. Vaughan (2002) states that Working as a psychotherapist, my thought is that spiritual intelligence opens the heart, illuminates the mind, and inspires the soul, connecting the individual human psyche to the underlying ground of being. Spiritual intelligence can be developed with practice and can help a person discriminate actuality from illusion.In this situation an attempt was made to ascertain therole of education on spiritual intelligence between science and arts undergraduate students. For this purpose we selected 80 students randomly from the faculty of science and faculty of arts in A.M.U. to meet the objectives and have a better idea and analysis to understand the student's behaviour. We applied the spiritual intelligence selfreport inventory developed by D. King in 2008. We analyseddata with the help of t- test. The obtained results revealed that the students of arts are more spiritual as compared to students of science. We have found the insignificant difference between both the groups on holy intelligence level.

Keywords: Education, Spiritual intelligence.

Learning is a life-long method by which an individual adapts himself/herself gradually and stylishly to the available bodily, academic, touching, communal and religious environments. Therefore, to carry out the process of education, teachers "as well as students" all round development should also be considered sincerely. Education is usual to provide ways and means for achieving the progress of body, intelligence and strength. The main director for this change is

1\&2 Department of Pychology, Aligarh Muslim University, Aligarh 


\section{Role of Education on Spiritual Intelligence between Science and Arts Undergraduate Students}

the teacher. So teachers are to be emotionally and spiritually mature enough to deal with the affecting and spiritual requirements of the students. During the pre-service agenda itself, the student-teachers need to be showing to emotional and spiritual development programme. Teachers do influence the character of students. Their emotional, logical, social and spiritual realms have profound influence on the development of children. Only teachers who are spiritually intelligent can encourage the development of students. Estimate of the important educational aspects is a basis for valuating educational institutes (Leenaars and Laster, 2006).

Educational getting estimation can be considered as one of the most important educational evaluations. Continuous evaluation of the students' educational achievement during their academic stage and analytical its efficient factors is one of the crucial and predictable bases of educational system improvement especially in the universities. It plays a prompting educational quality, and at last correcting and improving academic managers' efficiency (Bakhtiarpor, 2009). Students' academic performance in different fields, levels, and universities is educational factors. Determining appropriate criterions and factors is one of the potential research areas. Furnham, Chamorro, and Premuzic (2004), Gange and St Pere (2002), Lubinski (2004), Vigil are the authors who are active in this field. The scores of intelligence and academic achievement are one of the important measures that have been used as indicators for predicting students’ future conditions by several authors (Gange and St Pere, 2002).

Intelligence is one of the main characteristics that results in individual differences among peoples. This has been attended by humans from many years ago (Bakhtiarpor, 2009). Even if study about intelligence has focused on its cognitive aspects such as memory, problem emotional, social, and spiritual ability have been attended by authors. On the other hand, it can be used for predicting individual abilities for achievement. Wiggles Worth (2004) introduced four types of intelligence including physical, cognitive, emotional, and spiritual intelligences. He believes that the child find control on his body in the beginning of his life. In other words firstattention of mankind is his physical intelligence and then his linguistic and perceptual skills will be developed. Intelligence measure refers to the analysis capability that can be used in many educational activities. When an individual seeks to develop his/her relationship with others, emotional intelligence will be introduced (Golman, 2000). With regard to the emotions and their proper application in the human relations, some issues have been introduced as emotional intelligence such as understanding self and others' personality, continence and authority on the instant expectations, empathy, positive use of the emotions in thoughts and cognition (Kooker, Shoultz, and Codier, 2007). With regard to different levels of intelligence it can be concluded that these levels have especial interaction witheach other. However, beginning of the spiritual intelligence and its positive feedback results in improving emotional intelligence skills and spiritual intelligence (Samadi, 2006). 


\section{SIGNIFICANCE OF THE STUDY}

Today education plays a vital role in society. The purpose of this study is to highlight the importance of spiritual intelligence and its education on students. This paper will examine Role of education on spiritual intelligence between science and arts undergraduate students. In this research we have tried to recognize that at what extent and students' education related to spiritual intelligence.

\section{LITERATURE REVIEW}

\section{Education}

Education is a process, which plays an important role in the natural and orderly uplifting of an individual, Fred, A, .The major goal of education is holistic uplifting of students development. Educators are the core figure in the educational process which contributes to making individuals a prosperous successful individual. Educator s should make differences1. It is the educator who brings together the most invaluable materials i.e. boys and girls in their most flourishing effectively inspiring era of uplifting and development in the required forms. A fine educator is the necessity of the class and school. A nice educator rekindles a student's desire to learn; a valuable educator impresses that rekindle to make a fire that flames out for good. Educators must have the vital skills, personality character traits and conducts that students grasp to impact their motivation and inclining for learning. Since it is the educator's duty to relate with each student to nourish the passion, affection, desire and excitement to learn but with passing times top priorities and policies of educators have changed, it's not, just like attending classroom and delivering the lecture. They try todo their best to achieve the best in their lives. They also attempt to excel in their professional lives but in professional uplifting, spiritual intelligence as mentioned plays a significant part.

\section{Spiritual intelligence}

Spirituality is one of the inner needs of the human, which exists within the spirit, mind and in various religions. In fact, spirituality is the need of going away from us in the day-to-day life and becoming combined with another life other than ourselves. Progress and development of the science of psychology on the one part, and the difficult nature of the modern societies on the other part have caused the spiritual needs of the human-being to become more important, even more than the material needs. In reality, the spirituality is an eminent sense, which increases the human's interest and attitude of looking for justice and fairness, and causes him to create concord and affection with himself and the world. In the current decades, religious psychology and study on the theoretical subjects may be taken into the thought of the psychologists. Nowadays, the scientists have discovered that the general intelligence and even the emotional intelligence (emotional quotient) may not meet all needs of the human, but there is need for a 3rd factor, which is called Spiritual Intelligence. From the point of view of Emrem, spiritual intelligence includes the powers of operation and application, means of capabilities, values and the spiritual characteristics of the person in line with action and well-being in daily life. From the 
point of view of King, Spiritual Intelligence includes 4 components of existential thought, generation of personal meaning, growth of good sense and rising awareness. In general, Spiritual Intelligence combines the concepts of spirituality and intelligence in a new idea, and so, is a kind of intelligence which gives entirety and unity, and includes various methods, which may link the inner and spiritual life with the outer life, and at the end, may cause happiness and betterment of the living excellence.Vaugan (2003) has defined spirituality as a constant effort of human beings to answer the questions of life. Spirituality is one of inner needs of human beings. Some of the researchers consider it a guarantee of highest levels for cognitive, moral, emotional, and individual growth and stable effort of human beings to answer the question of life. In other words, best use of creativity and curiosity to find the active reasons related to survival and living and as a result growth and evolution constitutes an important part of spirituality (Shahidi, 2000).

\section{Importance of Spiritual intelligence in education to promote Innovators}

Education Spiritual Intelligence Innovator the teacher is supposed to be the main pillar in building a nation. It is the duty of the teacher to strengthen the new generation and to prepare the citizens to face boldly the present age of science and technology. Education for promoting relevant emotions needs to be recognized as an essential element of the educational process in the classroom since they strengthen the provided information, knowledge \& wisdom and direct attention and facilitate the attainment of goals. Only teachers who are spiritually intelligent can promote the spirituality of students. Teachers should be in a position to accept the scriptural view of the modern age as a challenge for new millennium, by thoroughly clarifying the value system. If the teacher is spirituallyintelligent, s/he can manage the spiritual traits of his/her students in order to provide fair environment in the classroom. Sense of identity, empathy, sympathy, suspicion, motivation, alertness, social skills, mercy, reconciliation, loyalty is some of the major components of spiritual intelligence. All these aspects are very much needed for the development (as a process or course of change) of appropriate qualities among students and hence among their teachers too.

\section{OBJECTIVES OF THE STUDY-}

There are following objectives of the present research.

1. To ascertain the role of education on spiritual intelligence among students.

2. To find out the difference between science and non-science students on spiritual intelligence.

3. To ascertain whether the students of different stream have different spiritual intelligence.

\section{NULL HYPOTHESIS}

1. There is no significance difference between science and non-science students on spiritual intelligence. 


\section{METHODOLOGY}

Research methodology involves the systematic procedure adopted in carrying the study by the researcher from initiation to its final conclusion.

\section{Participants}

For the current research, we selected 40 students from the faculty of science and 40 students from the other stream randomly to obtain data from Aligarh Muslim University.

\section{Tool}

For current research, we usedthe spiritual intelligence self-report inventory (SISRI-24) developed by D. King in 2008.This scale contains 24 items divided into four categories critical existential thinking(CET), personal meaning production (PMP), transcendenceawareness (TA) and conscious stat expansion(CSE). Split half reliability of this scale is .92and validity has been found satisfactory.

\section{Procedure}

We took the students from the campus into the confidence and established good rapport with them. We gave instructions related to the scale to all the subjects individually. We applied inventory on all the participants to obtain data andcollected inventories to data analysis. We have found result with the help of t-test to establish the difference between both the subjects group.

Table represents the difference between science and non- science students on spiritual intelligence by t-test

\begin{tabular}{|l|l|l|l|l|l|l|l|}
\hline Groups & Variable & number & df & $\begin{array}{l}\text { Mean } \\
\text { value }\end{array}$ & S.D. & t-value & Sig \\
\cline { 1 - 4 } $\begin{array}{l}\text { Science } \\
\text { students }\end{array}$ & \multirow{2}{*}{$\begin{array}{l}\text { Spiritual } \\
\text { intelligence }\end{array}$} & 40 & & 60.02 & 8.55 & & \\
\cline { 1 - 2 } $\begin{array}{l}\text { Non } \\
\text { science } \\
\text { students }\end{array}$ & & 40 & 39 & 63.10 & 11.71 & .22 & .22 \\
\hline
\end{tabular}

The above table shows that both the group of students have higher spiritual intelligence as it can be seen through the mean value which is 60.02 for science students and 63.10 for nonscience students but non science students have higher spiritual intelligence in comparison to nonscience students. The t value (1.23) reveals that there is no significant difference between both groups. It may be due to the some educational and religious environment. It is suggested that the same study be carried out on other groups (students, teachers, university students of other universities). In line with this study, broader studies with the use of more varied tools and 
differentiating between years of study and fields of study can help the generalizability of this study. Although using survey for data collection is a proper explanation, using more purpose tools such as interviews can add to the strength of such studies.

\section{IMPLICATIONS}

To enhance the level of spiritual intelligence students should listen stories to build up their trust towards god, improves knowledge of god. Tell them to read scriptures of various religions with regard to the concept of god and religiosity.Some meditational activities also prove useful for them. Show some pictures of famous people, present poem, read some of the salient features of Biographies to clear the concepts of conviction, commitment and character. Students should create a great "break spot" where students want to gather. This facilitates the informal communication that results in improved work and mental health and quality of life as it was found in the study of Moalemi reported by Nikbakht ASL (2010) concluded there is positive the correlation between spiritual intelligence and mental health. Between spiritual intelligence with dysfunctional thoughts exists negative relationship and there is a negative relationship between dysfunctional thoughts with mental health and spiritual intelligence.

We are not human beings having a spiritual experience; we are spiritual beings having a human experience.

\section{REFERENCES}

Bakhtiarpor, Saeid, (2009). Predicting the Students' Academic Achievement based on the Intelligence Quotient, Academic Experiences, and Demographic Variables in the university Psychology, 5 (26), pp. 81-94.

Furnham, A., \&Chamoro-Premuzic, T. (2004). Personality and intelligence as predictors of statistics examination grades. Personality and Individual Differences, 37, 943-955.

Goleman, D. (2000). An EI-based theory of performance. In D. Goleman, \& C. Cherniss (eds.), the EmotionallyIntelligent Workplace: How to Select for, Measure, and Improve Emotional Intelligence in Individuals, Groups, andOrganizations. San Francisco, CA:

Jossey-bass.Gange, F., \& St Pere, F. (2002). When IQ is controlled, does motivation still predict achievement? Intelligence. 30, 71-100.

Kooker, B.M \&Shoultz, J.andCodier, E. (2007). Identifying emotional intelligence in professional Nursing practice .Journal of professional Nursing, 23(1).30-36.

Leenaars, L., \& Lester, D. (2006). Perfectionism, depression, and academic performance.Psycol Rep. Vol. 9, PP.41-42.

Lubinski, D.(2004). Introduction to the special on cognitive abilities: 100 years after Spearmans (1904) 'General intelligence', objectively determined a 111.

Nikbakht ASL, M. (2010). Examine the relationship between personality traits and spiritual intelligence. MA Thesis, Unpublished, University of Sistan and Baluchestan. 
Samadi, Parvin, (2006). Spiritual Intelligence, New Educational Thoughts, 2 (3,4), pp. 99-114.

Shahidi, S. (2000). Psychotherapy and spirituality.Monthly conference of Iranian Society of Psychotherapists. Tehran, AndishehFarhangsara

Vaugan, F. (2003). What is Spiritual intelligence? Journal of humanistic psychology 42, (2).

Wiggles worth, C. (2004).Spiritual intelligence and why it matters. Retrieved from internet: www.consciouspursuits.com.

Zohar, D. \& Marshall, I. (2000). Spiritual Intelligence: The Ultimate Intelligence. London: Bloomsbury Publishing. 